\title{
Life history of the ground beetle Diacheila polita (Faldermann, 1835) (Coleoptera: Carabidae) in Subarctic and Arctic of North Europe and West Siberia
}

\author{
ЖКизненный цикл зкужкелиџы Diacheila polita (Faldermann, 1835) \\ (Coleoptera: Carabidae) в субарктике и арктике Северной Европы \\ и Западной Сибири
}

\author{
B.Yu. Filippov, N.A. Zubrii \\ Б.Ю. Фикиппов, Н.А. Зубрий
}

\begin{abstract}
N. Laverov Federal Center for Integrated Arctic Research of the Ural Branch of the Russian Academy of Sciences, Northern Dvina Emb. 23, 163000 Arkhangelsk, Russia. E-mail: fby@yandex.ru

Федеральный исследовательский центр комплексного изучения Арктики им. Н.П. Лаверова УрО РАН, наб. Северной Двины. 23 , 163002 Архангельск, Россия.
\end{abstract}

KEY WORDS: Life cycle, ground beetle, photoperiod, temperature conditions, Arctic, adaptation.

КЛЮЧЕВЫЕ СЛОВА: Жизненный цикл, жужелицы, фотопериод, температура, Арктика, адаптация.

ABSTRACT. The patterns of sex and age structure, seasonal activity of Diacheila polita under photoperiod and temperature conditions were studied in the North Europe and West Siberia within three bioclimatic zones: forest-tundra, southern tundra and typical tundra. A total of 7,963 adults and 24 larvae were collected using pitfall traps. All adults were dissected to determine their reproductive states. Adults of $D$. polita were active from the end of June until the beginning of September generally with one peak in August. Newly emerged and immature beetles had been catching in traps, from June or in the beginning of July. Mature adults had been registering from the end of June. At the end of August, more than 70\% of the studied populations were represented by mature adults. Larvae of $D$. polita had been catching from the second half of July to the beginning of August in tundra. The life cycle of $D$. polita is described as obligate-biennial late summer iteroparous. Seasonal mature adults activity is depended on daylight hours duration but not correlated with temperature conditions. Activity of mature females was more synchronized with photoperiod conditions than of mature males. The reduction of daylight hour's duration stimulated adult beetles to maturation and reproduction, and reaching the peak activity of individuals at the time when the daylight duration reaches $17-15$ hour in typical tundra and 16-15 hour in foresttundra and southern tundra.
РЕЗЮМЕ. Изучены закономерности половозрастной структуры и сезонной активности под действием фотопериода и температуры Diacheila polita в Северной Европе и Западной Сибири, в пределах трёх биоклиматических зон: лесотундре, южной тундре и типичной тундре. Всего с помощью ловушек было собрано 7963 имаго и 24 личинки. Все имаго были вскрыты для определения их репродуктивного состояния. Актиность D. polita длится с конца июня до начала сентября, как правило, с одним пиком в августе. С июня - начала июля в ловушки попадали ювенильные, и имматурные жуки. Генеративные особи ловились с конца июня. В конце августа более 70\% исследованных популяций были представлены генеративными особями. Личинки D. polita были собраны в тундре и попадались в ловушки со второй половины июля до начала августа. Жизненный цикл D. polita облигатно-двухгодичный позднелетний peцикличный. Сезонная активность генеративных особей зависит от длины светлого времени суток, но не зависит от температуры. Активность генеративных самок более синхронизирована с фотопериодом, чем у генеративных самцов. Сокращение продолжительности светлого времени суток стимулировало имаго к переходу в генеративное состояние и к размножению, пики активности особей приходились на время, когда продолжительность светового дня достигает 17-15 часов в типичной тундре и 16-15 часов в лесотундре и южной тундре.

How to cite this article: Filippov B.Yu., Zubrii N.A. 2021. Life history of the ground beetle Diacheila polita (Coleoptera: Carabidae) in Subarctic and Arctic of North Europe and West Siberia // Russian Entomol. J. Vol.30. No.4. P.393-400. doi: 10.15298/rusentj.30.4.03 


\section{Introduction}

Patterns of species distribution and range extension in most studies are explained by variability of environmental conditions or ecological niche of species [Bezdek, 2007; Jowetta, 2019, Knapp, 2019]. At the same time not all patterns of species expansions can be explain by variability of ecological factors [Schwartz, Ishchenko, 1971; Berman, 2007; Berman, Bulakhova, 2019], especially, in case of the absence of evident environmental limitations.

Field and laboratory experiments are supply data about environmental limitations in species distribution. One of the driven environmental factors affecting on adaptations of insects to Arctic and Subarctic are temperature conditions or shortage of heat supply [Balashov et al., 2011; Lopatina et al., 2012; Saska et al., 2014]. In this case lack of numerous species of insects in the Arctic is becoming clear. Among carabids beetles can transform their life cycle from one-year to two-year individual development for northward distribution [Filippov, 2007, 2008; Matalin, 2007, 2015]. At the same time, even carabid species with two-year life cycle have restrictions in distribution in high latitudes. Such pattern was detected for Holarctic species Diacheila polita (Faldermann, 1835), which is widely distributed in forest-tundra and tundra landscapes of Eurasia and North America [Lindroth, 1966, 1985]. Range of D. polita in Pleistocene reached North and West Europe up to British Islands. [Lindroth, 1985; Elias, 2010]. D. polita have a high density among carabids compositions in Subarctic but unclear causes are hold back its advance in high Arctic landscapes.

In this study, we explored (a) life-history characteristics of D. polita on the North Europe and West Siberia and (b) species seasonal activity under photoperiod and temperature conditions in the Arctic and Subarctic.

Table 1. Sampling localities and collected materials of D. polita in the North Europe and West Siberia Таблица 1. Районы исследования и объём собранного материала по D. polita в Северной Европе и Западной Сибири.

\begin{tabular}{|c|c|c|c|c|}
\hline $\begin{array}{l}\text { Bioclimatic } \\
\text { zonation }\end{array}$ & Locality, collecting period & $\begin{array}{l}\text { GPS } \\
\text { coordinates }\end{array}$ & $\begin{array}{l}\text { Pitfall trap- } \\
\text { days }\end{array}$ & $\begin{array}{c}\text { Imago } \\
\text { specimens } \\
\text { (number) }\end{array}$ \\
\hline Forest-tundra & $\begin{array}{l}\text { Polar Ural, } 10 \mathrm{~km} \text { from Kharp } \\
\text { settlement, 18.06-30.08.2017 }\end{array}$ & $\begin{array}{l}66^{\circ} 90^{\prime} \mathrm{N} \\
65^{\circ} 74^{\prime} \mathrm{E}\end{array}$ & 24852 & 169 \\
\hline $\begin{array}{l}\text { Southern tundra } \\
\text { (low shrub - } \\
\text { Subzone E) }\end{array}$ & $\begin{array}{l}\text { Kanin Peninsula, Shoyna settlement, } \\
\text { 14.06-28.08.2005 }\end{array}$ & $\begin{array}{l}67^{\circ} 49^{\prime} \mathrm{N} \\
44^{\circ} 13^{\prime} \mathrm{E}\end{array}$ & 28350 & 119 \\
\hline \multirow{3}{*}{$\begin{array}{l}\text { Typical tundra } \\
\text { (erect dwarf shrub } \\
\text { - Subzone D) }\end{array}$} & $\begin{array}{l}\text { Kolguev Island, Bugrino settlement, } \\
\text { 01.07-08.09.2009 }\end{array}$ & $\begin{array}{l}68^{\circ} 47^{\prime} \mathrm{N} \\
49^{\circ} 17^{\prime} \mathrm{E}\end{array}$ & 24160 & 5690 \\
\hline & $\begin{array}{l}\text { Yugorskiy Peninsula, Amderma } \\
\text { settlement, 17.06-07.09.2012 }\end{array}$ & $\begin{array}{l}69^{\circ} 42^{\prime} \mathrm{N} \\
61^{\circ} 41^{\prime} \mathrm{E}\end{array}$ & 35860 & 1609 \\
\hline & $\begin{array}{l}\text { Yamal Peninsula, Seyakha } \\
\text { settlement, 28.06-02.09.2014 }\end{array}$ & $\begin{array}{l}70^{\circ} 10^{\prime} \mathrm{N} \\
72^{\circ} 30^{\prime} \mathrm{E}\end{array}$ & 18921 & 376 \\
\hline \multicolumn{3}{|l|}{ Total: } & 132143 & 7963 \\
\hline
\end{tabular}

\section{Materials and methods}

Study sites and material collection

Field works were conducted by «local fauna» method by latitudinal gradient [Penev, 1996; Makarov, Matalin, 2009]. Specimens of D. polita were collected within 5 localities in North Europe and West Siberia (Table 1). Latitudinal gradient included locations within three bioclimatic zones: forest-tundra in Subarctic, southern tundra and typical tundra in Arctic (Table 1) [Walker et al., 2005].
Ground beetles were collected using pitfall traps [Barber, 1931; Heydemann, 1956] — $500 \mathrm{ml}$ plastic cups with a trap hole diameter of $93 \mathrm{~mm}$. In each site 10-25 traps were installed in lines with a distance of $10 \mathrm{~m}$ between traps and lines. For insects fixation 4\% formaldehyde solution was used. The material was sampled from the traps once every ten days. As result, 1929 traps were installed for a total of 132,143 trap-days and 7,963 specimens of $D$. polita imago were sampled (Table 1). Larvae were recorded for the Kolguyev Is-

Table 2. Number of catching larvae of D. polita on Kolguyev Island in 2009. Таблица 2. Количество личинок D. polita, собранных на острове Колгуев в 2009 г.

\begin{tabular}{|l|c|c|c|c|c|c|c|c}
\hline Instar larvae & I.07* & II.07 & III.07 & I.08 & II.08 & III.08 & I.09 & Total \\
\hline II & 0 & 1 & 2 & 0 & 0 & 0 & 0 & 3 \\
\hline III & 0 & 4 & 12 & 1 & 0 & 0 & 0 & 20 \\
\hline Total & 0 & 5 & 20 & 1 & 0 & 0 & 0 & 23 \\
\hline
\end{tabular}

* I, II, III — ten-day periods.

* I, II, III - декады. 
land (Table 2) and four third instar larvae were trapped in southern tundra of Kanin Peninsula: one larva in the middle of July and another three larvae in the last tenday period of July.

The average air temperature and the polar day duration for studied localities for each ten-day period in June-September (when was D. polita was collected, see Table S1) were obtained from the records of the local meteorological stations (www.rp5.ru, my-calend.ru last accessed on $20^{\text {th }}$ of August 2020).

Age determination and seasonal activity

The analysis of the age of both sexes in populations was performed by the method of Wallin [1989]. Adults of both sexes were dissected to determine the developmental stage of their gonads of the following five reproductive states: teneral, immature, mature, old-mature and spent (Table S2). Also, D. polita specimens with parasitic invasions by representatives of the class Gordiacea were excluded from the analysis because it was impossible to determine reproductive states of imago (Table S2).

Seasonal activity was described using the total number of caught specimens and peak of activity was registered in days when $50 \%$ of the total number of individuals were caught. Life-history patterns of $D$. polita were studied by seasonal variations of different reproductive states of specimens.

\section{Statistical analysis}

For data analysis the total number of specimens caught and their seasonal activity were used. Seasonal activity was calculated as the numbers of individuals trapped per 10 trap-days (ind/10 t-d) (Table S1).

One of questions of our research concerned the regulation of breeding period; therefore, the latitude of sampling localities was included as a covariate in the general linear model (GLM), which explored the sources of variation in seasonal activity of mature adults.

The relationships between seasonal activity of mature adults, mean temperature and daylight duration for each locality, were explored by calculating Spearman's rs correlation coefficient. Data analysis was conducted using both STATISTICA v.10 and PAST v.3.06 [Hammer, 2015].

\section{Results}

\section{Seasonal activity and reproduction}

Among study localities the entire activity period of D. polita was lasted from the end of June until the beginning of September generally with one peak in August (Table S2). Two peaks of adults activity were registered for Yugorskiy Peninsula in the end of July and in the end of August. Seasonal activity of different reproductive states of imago was visualized for Kolguyev Island (Fig. 1, for other studied populations see Table S2). Beginning of activity started after snow melt period in the end of June or in the beginning of July and newly emerged and immature beetles were predominated in study populations. Immature individuals were trapped until September in all studied populations. Activity peak of teneral beetles of $D$. polita was lasted from the end of August to the beginning of September. Mature

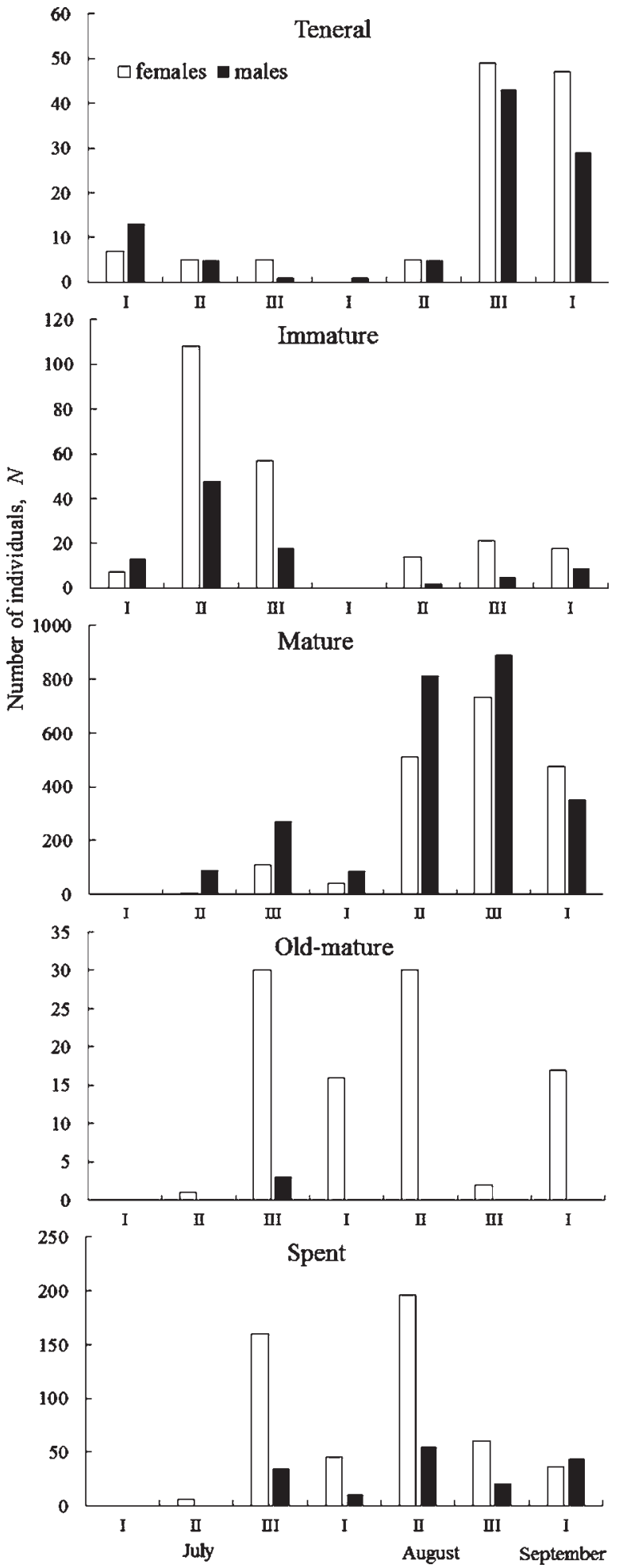

Fig. 1. Sex and age structure of the population of D.polita according to collecting by pitfall traps on Kolguyev Island in 2009.

Рис. 1. Поло-возрастная структура популяции D. polita по данным учётов почвенными ловушками на о-ве Колгуев в 2009 г. 
adults were recorded from the first half of July. More than $75 \%$ of the population was represented by mature adults, in the middle of August in typical tundra (Yamal Peninsula and Kolguyev Island) (Fig. 1). Peak of mature adults in forest-tundra of Polar Ural (72\% of the population) and in southern tundra of Kanin Peninsula (76\% of the population) was detected in the end of August. Early peak of mature adults (91,6\% of the population) in
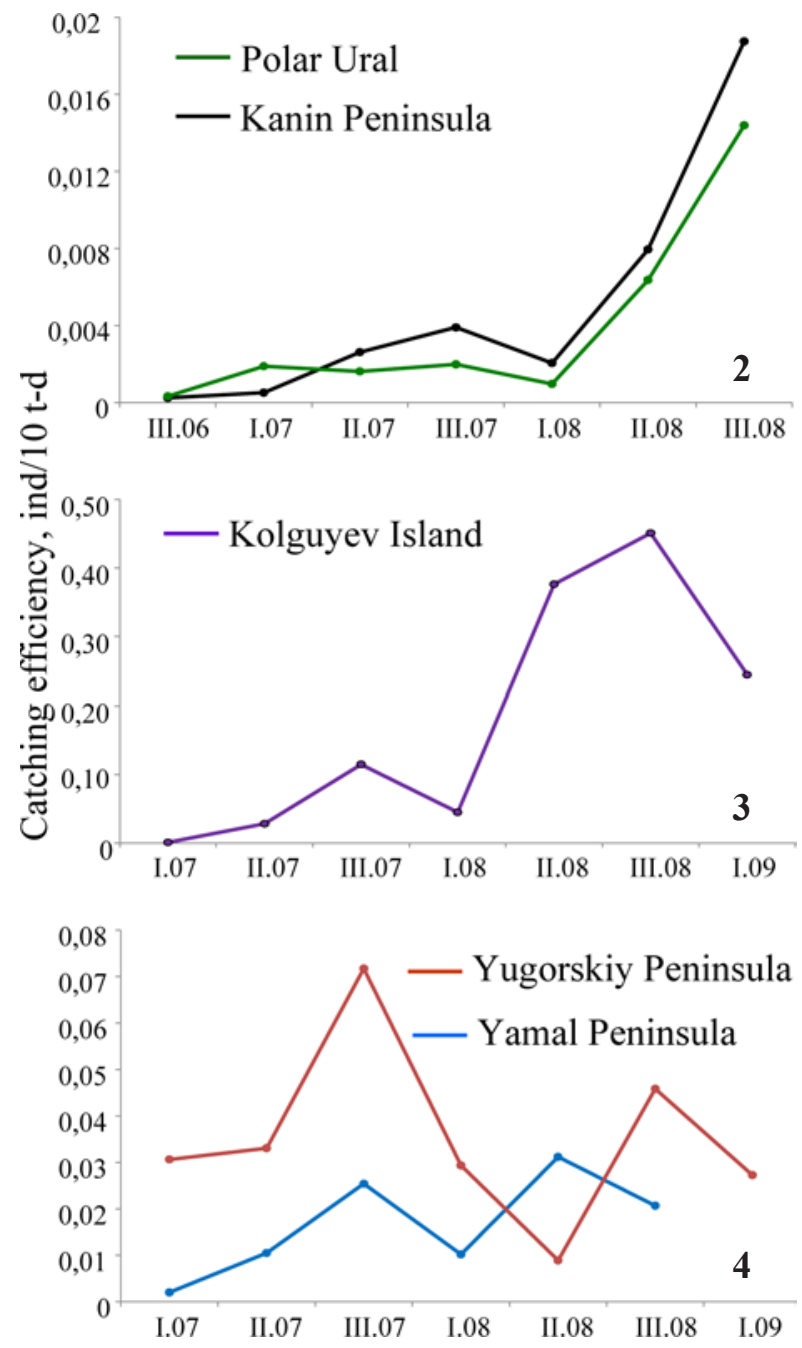

Figs 2-4. Seasonal mature adults activity of D. polita: 2 - foresttundra and southern tundra; 3-4 - typical tundra (see Tables 1, S1).

Рис. 2-4. Сезонная активность половозрелых имаго D. polita: 2 - лесотундра и южная тундра, 3-4 - типичная тундра (см. таблицы 1 и S1). the end of July was registered for Yugorskiy Peninsula, but the second one was in time with others peaks of $D$. polita in typical tundra. Larvae of $D$. polita on Kolguev Island were catching from the second week of July to the first week of August and one peak activity was recorded in the end of July (Table 2).

\section{Regulation of seasonal activity}

Males and females of $D$. polita became active at the same time in trapping seasons and demonstrated the common trend for all studied populations $(r=0.91 ; n=$ $35, P<0.001)$. Seasonal activity of mature adults was different between localities and, despite different years of beetles collection, the catching efficiency of $D$. polita increase from forest-tundra ( 0.03 ind./10 t-d) and southern tundra $(0.04 \mathrm{ind} / 10 \mathrm{t}-\mathrm{d})$ to typical tundra $(1.26-0.10$ ind/10 t-d) (Figs 2-4, Table S1).

The mature adults activity is differently changed with latitude (Table 3) and increased with lightday shortening for studied populations of D. polita except the population of the Yugorskiy Peninsula (Table S1). Females catching efficiency was stronger correlated with day duration (from $r=-0.85$ to $r=-0.94$ ) than males activity (from $r=-0.79$ to $r=-0.88$ ). Males activity shown absence of significant association with photoperiod in typical tundra on the Yamal Peninsula $(r$ $=-0,38 ; n=7, P=0,45)$. General trend shows that peaks with maximum mature adults' activity of both sexes of D. polita were detected in days with 17-15 hours of lighting period and their catching efficiency is decreased in days shorter than 14 hours (Table S1). An exception was activity of mature adults from population of the Yugorskiy Peninsula. Maximal number of individuals was caught there in the end of July immediately after the end of polar day (Table S1). Seasonal change of mean air temperature did not correlate with mature adults activity (Table S1). In typical tundra the period of adult activity of $D$. polita was decreased when mean daily temperature dropped below $6^{\circ} \mathrm{C}$ (Table $\left.\mathrm{S} 1\right)$.

\section{Discussion}

Seasonal activity and reproduction

The seasonal activity of $D$. polita recorded in this study shows that adults were active from the end of June till September generally with a single peak in August. This activity patterns is common for populations from

Table 3. Sources of variation in mature adults' seasonal activity of $D$. polita (GLMs). Таблица 3. Факторы, влияющие на сезонную активность половозрелых имаго D. polita (GLM).

\begin{tabular}{|l|c|c|c|c|c|c|}
\hline \multirow{2}{*}{ Response variable } & \multicolumn{3}{|c|}{ Females } & \multicolumn{3}{c|}{ Males } \\
\cline { 2 - 7 } & $\mathrm{df}$ & $\mathrm{F}$ & $\mathrm{p}$ & $\mathrm{df}$ & $\mathrm{F}$ & $\mathrm{p}$ \\
\hline Latitude & 4 & 14.87 & 0.000001 & 4 & 6.611 & 0.0006 \\
\hline Mean temperature & 1 & 0.012 & 0.905 & 1 & 0.012 & 0.926 \\
\hline Polar day duration & 1 & 12.12 & 0.0012 & 1 & 4.65 & 0.033 \\
\hline Latitude $\times$ Polar day duration & 4 & 10.54 & 0.000017 & 4 & 4.231 & 0.0068 \\
\hline Error & 25 & & & 25 & & \\
\hline
\end{tabular}


forest-tundra to typical tundra of North Europe and West Siberia. Two peaks of adults' activity in July and August were registered in typical tundra of the Yugorskiy Peninsula. Data on larval activity was scarce and have been registered in typical tundra of the Kolguyev Island from the end of July to the beginning of August and in southern tundra of the Kanin Peninsula at the same period. Mature adults were recorded from the first half of July and showed peaks of activity from the second to the third ten-day period of August. Reproduction period of $D$. polita for most of studied populations lasted three ten-days period from the end of August to the beginning of September. An activity peak of teneral beetles was detected during the reproduction period of $D$. polita. Teneral adults were also recorded at the beginning of an activity season. Third instar larvae of $D$. polita were trapped in southern tundra and typical tundra in the end of July. This fact evidences about the pupation in the beginning of August. Newly emerged beetles were registered in the end of August and they hibernate in the imaginal stage. This corresponds with catch of immature beetles in the end of August from North America by Lindroth [1961] and from August to September on the Kola Peninsula and in Norway [Hanssen, Olsvik, 1998]. Teneral beetles are reached maturity at the second part the summer of the next year.

We concluded that $D$. polita develops during two years, overwinters as larva and as adult, adult lives more than one year, and the different reproductive states and generations overlap during one seasons. Old-mature beetles participate in the reproduction and assuring the persistence of the population. Thus, according to the life-cycles typology [Matalin, 2007] D. polita is obligate-biennial late summer iteroparous species (Fig. 5). Our result corresponds to previous conclusions about increasing proportion of species with two-year lifecycle in carabids faunas along the latitudinal gradient to north or along the altitudinal gradient to height in mountains [Paarmann, 1979; Sota, 1994; Sharova, Filippov, 2003; Matalin, 2007]. In instance on the North of Russian Plain the proportions of carabids species with twoyear life cycle rise up from $40 \%$ in taiga to $60 \%$ in tundra [Filippov, 2008].

\section{Seasonal activity regulation}

Mature adults activity of $D$. polita was from seven to eight ten-day periods among studied populations. Nevertheless, the highest catching efficiency of mature adults was registered in two last ten-days period of August due to photoperiod conditions. Under condition of a polar day reduction adult beetles were stimulated to maturation and reproduction, and reaching the peak activity of individuals at the time when the daylight duration reaches 17-15 hour in typical tundra and 16-15 hour in forest-tundra and southern tundra. Similar adaptation to Subarctic was studied for Pterostichus nigrita (Paykull, 1790). For this species the ovaries, remained undeveloped in constant long and day night duration of 2-4 hours, are still enough to enable the maturation processes in population of Northern Sweden (Lapland, $65^{\circ} \mathrm{N}$ ) [Thiele, 1979]. The optimal light period for P. nigrita was about 15 hours and the critical photoperiod is about 13 hours per 24 hours [Thiele, 1979]. For D. polita the day shorter than 14 hour of lighting period suppresses the mature adults activity and induces diapause in the typical tundra. Also, activity of mature females was more synchronized with photoperiod conditions than in mature males. Such pattern, with weakening of photoperiodic control of gonad maturation in males more than in females, was detected for Pterostichus adstrictus Eschscholtz, 1823 [Paarmann, 1994]. The both sexes of adult beetles in typical tundra of the Yugorsky Peninsula had not significant correlations with photoperiod conditions, as well as mature males from population of the Yamal Peninsula, but demonstrated common patterns of seasonal activity of $D$. polita in typical tundra. Seasonal changing of mean air temperature was not associated with adult beetles activity of $D$. polita. Photoperiodic control of gonad maturation for carabid beetles has a high influence in temperate zone and loses this influence in the Subarctic [Paarmann, 1979]. Species in the Arctic may lost reaction to a change of photoperiod and the ability of synchronizing of the egg laying period with the annual climate change gain a great importance, which was shown for P. adstrictus [Paarmann, 1994].

Apparently, northward distribution of D. polita is limited by temperature conditions of localities that pro-

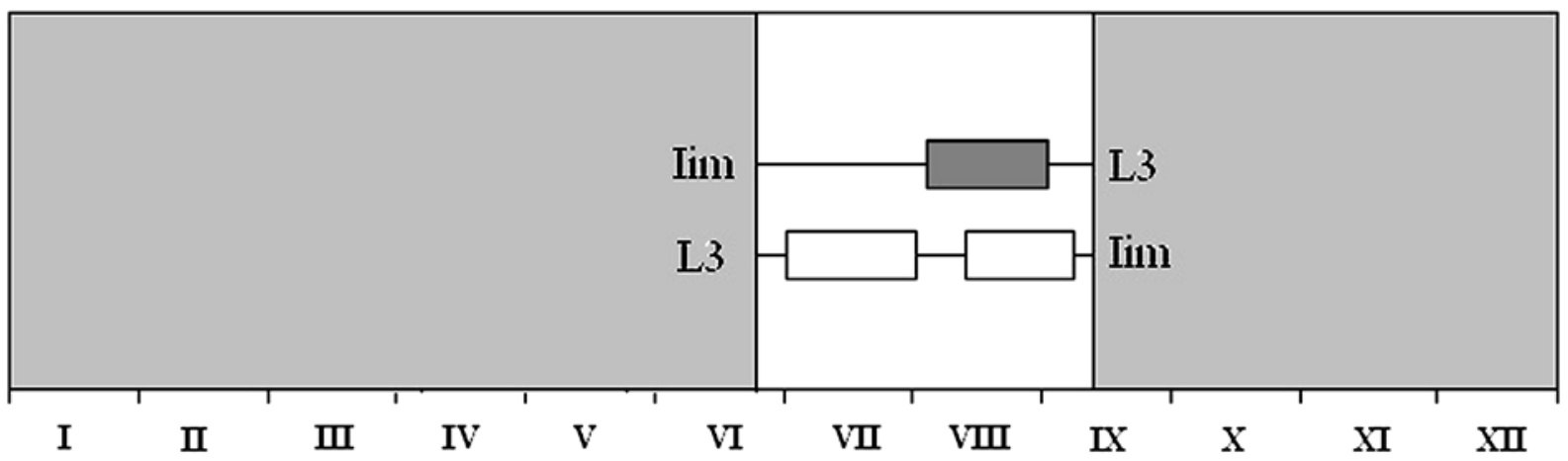

Fig. 5. Two years life cycle of $D$. polita with activity season — white color and hibernation — grey color; L3 — third instar larvae, Iim - immature; White rectangle - teneral, grey rectangle — mature.

Рис. 5. Двухгодичный жизненный цикл D. polita с периодом активности (белый фон) и зимней спячки (серый фон); L3 - личинки третьего возраста, Iim — неполовозрелые имаго; молодые особи обозначены белым прямоугольником, половозрезые - серым. 
vide to develop within two-year life cycle and photoperiod conditions, witch regulate of seasonal activity and reproduction. So, for cold-adaptive $D$. polita with twoyear life- cycle the photoperiodic regulation of maturation and breeding can restrict species distribution in high Arctic. Ability to develop without dormancy during summer or winter over a wide temperature range as found for Pterostichus brevicornis given more opportunity for success distribution in the Arctic [Paarmann, 1994].

Acknowledgements: This research was supported by the Russian Foundation for Basic Research project number 1934-60042 and project number AAAA-A17-1170330101322 of the Ministry of Science and Higher Education of the Russian Federation.

Competing interests. The authors declare no competing interests.

\section{References}

Balashov S.V., Kipyatkov V.E., Filippov B.Yu. 2011. [Comparative studies of the thermal conditions of the habitats of ground beetles (Coleoptera: Carabidae) in the European part of Russia] // Vestnik Saint Petersburg University. Ser.3: Biology. No.2. P.3-12 [in Russian with English summary].

Barber H. 1931. Traps for cave - inhabiting insects // J. Elisha Mitchell Sci. Soc. Vol.46. No.3. P.259-266.

Berman D.I. 2007. [Animal ecology of northeast Asia and the reconstruction of the Pleistocene landscapes of Beringia]. Ph.D. thesis in biological sciences. Moscow. 56 pp. [In Russian]

Berman D.I., Bulakhova N.A. 2019. [How Winterkill Suffocations Stop the Common Frog Spreading from Europe to Asia] // Priroda. No.7. P.12-20 [in Russian, with English summary]

Bezdek A., Jaroš K.J., Spitzer K. 2007. Spatial distribution of ground beetles (Coleoptera: Carabidae) and moths (Lepidoptera) in the Mrtv luh bog, Šumava Mts (Central Europe): a test of habitat island community // Biodiversity and Conservation. No.1. P.381-395.

Elias S.A. 2010. Advances in Quaternary Entomology // Developments in Quaternary Sciences. Amsterdam: Elsevier. Vol.12. $288 \mathrm{pp}$.

Filippov B.Yu. 2007. [Life cycles of some species of carabid beetles (Coleoptera: Carabidae) in the south tundra] // Russian Entomological Journal. Vol.16. No.4. P.425-438 [in Russian].

Filippov B.Yu. 2008. [Ways of adaptation and ecological patterns of development by ground beetles (Coleoptera, Carabidae) in the north of the Russian Plain]. Dissertation for the degree of Doctor of Biological Sciences. Moscow. 41 pp. [In Russian]

Hammer Ø. 2015. PAST: Paleontological Statistics Version 3.06: Reference manual. Natural History Museum University of Oslo. Norway. $225 \mathrm{p}$.

Hanssen O., Olsvik P. 1998. Diacheila polita (Faldermann, 1835) (Col., Carabidae) new to Norway // Fauna norv. Ser.B. Vol.45. P.116-118.

Heydemann B. 1956. Über die Bedeutung der «Formalinfallen» für die zoologische Landesforschung//Faun. Mitt. Norddeutschland. Bd.6. S.19-24.

Jowetta K., Milnea A. ., Metcalfe H. 2019. Species matter when considering landscape effects on carabid distributions // Agriculture, Ecosystems and Environment. Vol.285. No.1. Electronic text data. doi.org/10.1016/j.agee.2019.106631.

Knapp M., Seidl M., Knappová J., Macek M., Saska P. 2019. Temporal changes in the spatial distribution of carabid beetles around arable field-woodlot boundaries // Scientific Reports. No.9. 8967. doi:10.1038/s41598-019-45378-7.

Lindroth C.H. 1966. The ground beetles (Carabidae excl. Cicindelinae) of Canada and Alaska. Part 4 // Opuscula entomologica supplementa. Vol.29. P.409-648.

Lindroth C.H. 1985. The Carabidae (Coleoptera) of Fennoscandia and Denmark // Fauna Entomologica Scandinavica. Copenhagen: E.J. Brill/Scandinavian Science Press Ltd. Vol.15. Pt.1. 497 pp.

Lindroth C.H. 1961. The Ground-Beetles (Carabidae, excl. Cicindelinae) of Canada and Alaska. Part 2. // Opusc. Ent. Suppl.20. P.1-200.

Lopatina E.B., Kipyatkov V.E., Balashov S.V., Dubovikoff D.A., Sokolova I.V. 2012. Adaptive latitudinal variation of the duration and thermal requirements for development in the ground beetle Amara communis (Panz.) (Coleoptera, Carabidae) // Entomological Review. Vol.92. P.135-145.

Makarov K.V., Matalin A.V. 2009. Ground-beetle communities in the Lake Elton region, southern Russia: a case study of a local fauna (Coleoptera, Carabidae) // Babenko A.B., Matveeva N.V., Makarova O.L. Golovach S.I. (eds.). Species and Communities in Extreme Environments. Festschrift towards the 75th Anniversary and a Laudatio in Honour of Academician Yuri Ivanovich Chernov. Sofia-Moscow: Pensoft Publishers \& KMK Scientific Press Ltd. P.357-384.

Matalin A.V. 2007. Typology of life cycles of ground beetles (Coleoptera, Carabidae) in Western Palaearctic // Entomological review. Vol.87. No.8. P.947-972.

Matalin A.V. 2015. Specific manifestations of polyvariant life cycles in ground beetles (Coleoptera, Carabidae) along a latitudinal gradient // Biology Bulletin. Vol.42. No.6. P.526-530. DOI: $10.1134 / \mathrm{S} 1062359015660036$.

Paarmann W. 1979. Ideas about the evolution of the various annual reproduction rhythms in carabid beetles of the different climatic zones // Miscellaneous Papers 18. Landbouwhogeschool Wageningen. P.119-132.

Paarmann W. 1994. Temperature and photoperiodic influence on developmental stages and adults of the subarctic carabid beetle Pterostichus adstrictus (Coleoptera) // Carabid Beetles: Ecology and Evolution. Series entomologica. Vol.51. P.201-205.

Penev L. 1996. Large-scale variation in carabid assemblages, with special reference to the local fauna concept. // Ann. Zool. Fenn. Vol.33. P.49-63.

Saska P., Vlach M., Schmidtová J., Matalin A.V. 2014. Thermal constants of egg development in carabid beetles - variation resulting from using different estimation methods and among geographically distant European populations // European Journal of Entomology. Vol.111. P.621-630.

Sharova I.Kh., Filippov B.Yu. 2003. Peculiarities of ground beetle (Coleoptera, Carabidae) life cycles in northern taiga // Entomological review. Vol.82. No.2. P.229-238.

Schwartz S.S., Ishchenko V.G. 1971. [Ways of adaptation of terrestrial vertebrates to the conditions of existence in the Subarctic. T. 3. Amphibian]. Sverdlovsk: UFAN SSSR. 60 pp. [In Russian]

Sota T. 1994. Variation of carabid life cycles along climatic gradients: an adaptive perspective for life-history evolution under adverse conditions // Series Entomologica. Vol.52. P.91-112.

Thiele H.U. 1979. Intra specific differences in photoperiodism and measurement of day length in Pterostichus nigrita Paykull (Coleoptera, Carabidae) // On the evolution of behaviour in carabid beetles. Wageningen. P.53-62.

Wallin H. 1989. The influence of different age classes on the seasonal activity and reproduction of four medium-sized carabid species inhabiting cereal fields // Holarct. Ecol. Vol.12. No.3. P.201212.

Walker D.A., Raynolds M.K., Daniëls F.J.A., Einarsson E., Elvebakk A., Gould W.A., Katenin A.E., Kholod S.S., Markon C.J., Melnikov E.S., Moskalenko N.G., Talbot S.S., Yurtsev B.A. \& the other members of the CAVM Team. 2005. The Circumpolar Arctic vegetation map. // J. Veget. Sci. Vol.16. P.267-282. 
Supplementary materials

Table S1. Polar day duration, average air temperature, catching efficiency (individuals/10 trap $\times$ days) of $D$. polita of studied localities

Таблица S1. Продолжительность полярного дня, средняя температура воздуха, уловистость (особей/10 ловушек×сут) D. polita изученных местообитаний

\begin{tabular}{|c|c|c|c|c|c|}
\hline Local fauna & Decade.Month & $\begin{array}{l}\text { Polar day } \\
\text { duration } \\
\text { (hours) }\end{array}$ & $\begin{array}{c}\text { Average air } \\
\text { temperature } \\
\left(\mathrm{T},{ }^{\circ} \mathrm{C}\right)\end{array}$ & $\begin{array}{l}\text { Catching } \\
\text { efficiency of } \\
\text { female }\end{array}$ & $\begin{array}{c}\text { Catching } \\
\text { efficiency of } \\
\text { male }\end{array}$ \\
\hline \multirow{7}{*}{$\begin{array}{l}\text { Polar Ural, } 10 \mathrm{~km} \text { from } \\
\text { Kharp settlement }\end{array}$} & III.06 & 24,00 & 12,9 & 0,00066 & 0,00066 \\
\hline & 1.07 & 23,03 & 12,5 & 0,00081 & 0,00161 \\
\hline & II.07 & 20,52 & 18,2 & 0,00129 & 0,00162 \\
\hline & III.07 & 19,09 & 18,9 & 0,00099 & 0,00223 \\
\hline & $\mathrm{I} .08$ & 17,45 & 10,4 & 0,00121 & 0,00097 \\
\hline & II.08 & 16,26 & 10,3 & 0,00727 & 0,00879 \\
\hline & III.08 & 15,02 & 12,0 & 0,00875 & 0,01157 \\
\hline \multicolumn{4}{|l|}{ Spearman's rs* } & $\begin{array}{l}\mathrm{r}=-0,89 \\
\mathrm{P}=0,012\end{array}$ & $\begin{array}{l}r=-0,79 \\
P=0,048\end{array}$ \\
\hline \multirow{7}{*}{$\begin{array}{l}\text { Kanin Peninsula, } \\
\text { Shoyna settlement }\end{array}$} & III.06 & 24,00 & 7,8 & 0,00000 & $\begin{array}{r}0,00024 \\
\end{array}$ \\
\hline & 1.07 & 24,00 & 6,1 & 0,00026 & 0,00026 \\
\hline & II.07 & 22,01 & 12,5 & 0,00024 & 0,00237 \\
\hline & III.07 & 19,45 & 14,4 & 0,00028 & 0,00362 \\
\hline & $\mathrm{I} .08$ & 18,09 & 4,0 & 0,00103 & 0,00103 \\
\hline & II.08 & 16,43 & 6,2 & 0,00179 & 0,00615 \\
\hline & III.08 & 15,13 & 5,5 & 0,00875 & 0,01000 \\
\hline \multicolumn{4}{|l|}{ Spearman's rs } & $\begin{array}{l}r=-0,94 \\
P=0,004\end{array}$ & $\begin{array}{l}r=-0,88 \\
P=0,015\end{array}$ \\
\hline \multirow{7}{*}{$\begin{array}{l}\text { Kolguyev Island, } \\
\text { Bugrino settlement }\end{array}$} & I.07 & 24,00 & 5,4 & 0,00000 & 0,00122 \\
\hline & II.07 & 24,00 & 9,0 & 0,00199 & 0,02639 \\
\hline & III.07 & 20,34 & 10,7 & 0,03833 & 0,07667 \\
\hline & $\mathrm{I} .08$ & 18,31 & 7,7 & 0,01790 & 0,02716 \\
\hline & II.08 & 16,57 & 9,3 & 0,15056 & 0,22583 \\
\hline & III.08 & 15,30 & 7,4 & 0,20361 & 0,24750 \\
\hline & 1.09 & 14,15 & 10,1 & 0,14207 & 0,10243 \\
\hline \multicolumn{4}{|l|}{ Spearman's rs } & $\begin{array}{l}r=-0,85 \\
P=0,025\end{array}$ & $\begin{array}{l}r=-0,84 \\
P=0,025\end{array}$ \\
\hline \multirow{8}{*}{$\begin{array}{l}\text { Yugorskiy Peninsula, } \\
\text { Amderma settlement }\end{array}$} & III.06 & 24,00 & 12,4 & 0,00563 & $\begin{array}{r}0,00985 \\
\end{array}$ \\
\hline & 1.07 & 24,00 & 9,1 & 0,01587 & 0,01478 \\
\hline & II.07 & 24,00 & 11,9 & 0,01565 & 0,01739 \\
\hline & III.07 & 21,11 & 11,6 & 0,03326 & 0,03848 \\
\hline & 1.08 & 18,58 & 8,7 & 0,01739 & 0,01196 \\
\hline & II.08 & 17,14 & 7,1 & 0,00435 & 0,00457 \\
\hline & III.08 & 15,32 & 7,6 & 0,02457 & 0,02130 \\
\hline & 1.09 & 14,04 & 6,1 & $\begin{array}{r}0,01712 \\
\end{array}$ & 0,01015 \\
\hline \multicolumn{4}{|l|}{ Spearman's rs } & $\begin{array}{l}r=-0,32 \\
P=0,45\end{array}$ & $\begin{array}{l}r=-0,12 \\
P=0,79\end{array}$ \\
\hline \multirow{6}{*}{$\begin{array}{l}\text { Yamal Peninsula, } \\
\text { Seyakha settlement }\end{array}$} & $\mathrm{I} .07$ & 24,00 & 7,2 & 0,00051 & 0,00152 \\
\hline & II.07 & 24,00 & 6,2 & 0,00401 & 0,00648 \\
\hline & III.07 & 21,50 & 8,0 & 0,00902 & 0,01639 \\
\hline & I.08 & 19,18 & 7,0 & 0,00641 & 0,00379 \\
\hline & II.08 & 17,28 & 8,2 & 0,01481 & 0,01636 \\
\hline & III.08 & 15,41 & 6,4 & 0,01204 & $\begin{array}{r}0,00864 \\
\end{array}$ \\
\hline \multicolumn{4}{|l|}{ Spearman's rs } & $\begin{array}{l}r=-0,85 \\
P=0,03\end{array}$ & $\begin{array}{l}r=-0,38 \\
P=0,45\end{array}$ \\
\hline
\end{tabular}

Legend:* Spearman's correlations between seasonal activity of mature adults and daylight duration

Легенда: * Корреляция по Спирмену между сезонной активностью взрослых взрослых особей и продолжительностью светового дня. 
Table S2. Seasonal changes of age stage $D$. polita in different local fauna (individuals) Таблица S2. Сезонная динамика репродуктивных стадии D. polita в разных локальных фаунах (экз.)

\begin{tabular}{|c|c|c|c|c|c|c|c|c|c|c|}
\hline \multirow{2}{*}{ Local fauna } & \multirow{2}{*}{ Sex } & \multirow{2}{*}{ Age } & \multicolumn{8}{|c|}{ Decade.Month } \\
\hline & & & III.06 & I.07 & II.07 & III.07 & I.08 & II.08 & III.08 & 1.09 \\
\hline \multirow{10}{*}{$\begin{array}{l}\text { Polar Ural, } 10 \\
\text { km from Kharp } \\
\text { settlement }\end{array}$} & \multirow{5}{*}{ Female } & $\mathrm{t}$ & 0 & 0 & 0 & 0 & 0 & 8 & 5 & 13 \\
\hline & & $\mathrm{im}$ & 0 & 0 & 1 & 3 & 2 & 6 & 3 & 16 \\
\hline & & $\mathrm{m}$ & 1 & 6 & 4 & 6 & 2 & 13 & 33 & 65 \\
\hline & & $\mathrm{m} 2$ & 0 & 0 & 0 & 0 & 0 & 0 & 0 & 0 \\
\hline & & $\mathrm{sp}$ & 0 & 0 & 0 & 0 & 0 & 0 & 0 & 0 \\
\hline & \multirow{5}{*}{ Male } & $\mathrm{t}$ & 0 & 0 & 0 & 1 & 2 & 15 & 10 & 28 \\
\hline & & $\mathrm{im}$ & 1 & 2 & 2 & 1 & 0 & 0 & 3 & 9 \\
\hline & & $\mathrm{m}$ & 0 & 1 & 1 & 4 & 2 & 8 & 18 & 32 \\
\hline & & $\mathrm{m} 2$ & 0 & 0 & 0 & 1 & 0 & 0 & 0 & 1 \\
\hline & & $\mathrm{sp}$ & 0 & 0 & 0 & 0 & 0 & 0 & 0 & 0 \\
\hline \multirow{10}{*}{$\begin{array}{l}\text { Kanin } \\
\text { Peninsula, } \\
\text { Shoyna } \\
\text { settlement }\end{array}$} & \multirow{5}{*}{ Female } & $t$ & 0 & 0 & 0 & 0 & 0 & 1 & 1 & - \\
\hline & & $\mathrm{im}$ & 0 & 0 & 1 & 0 & 1 & 7 & 2 & - \\
\hline & & $\mathrm{m}$ & 0 & 1 & 1 & 1 & 2 & 6 & 6 & - \\
\hline & & $\mathrm{m} 2$ & 0 & 0 & 0 & 0 & 2 & 1 & 1 & - \\
\hline & & $\mathrm{sp}$ & 1 & 0 & 1 & 0 & 0 & 1 & 0 & E- \\
\hline & \multirow{5}{*}{ Male } & $t$ & 0 & 0 & 0 & 0 & 0 & 1 & 0 & - \\
\hline & & $\mathrm{im}$ & 0 & 0 & 0 & 1 & 0 & 0 & 0 & - \\
\hline & & $\mathrm{m}$ & 1 & 1 & 10 & 13 & 4 & 24 & 8 & - \\
\hline & & $\mathrm{m} 2$ & 0 & 0 & 0 & 0 & 0 & 0 & 0 & - \\
\hline & & sp & 0 & 0 & 0 & 0 & 0 & 0 & 0 & - \\
\hline \multirow{10}{*}{$\begin{array}{l}\text { Kolguyev } \\
\text { Island, Bugrino } \\
\text { settlement }\end{array}$} & \multirow{5}{*}{ Female } & $\mathrm{t}$ & - & 7 & 5 & 5 & 0 & 5 & 49 & 47 \\
\hline & & $\mathrm{im}$ & - & 7 & 108 & 57 & 0 & 14 & 21 & 18 \\
\hline & & $\mathrm{m}$ & - & 0 & 6 & 108 & 42 & 512 & 731 & 474 \\
\hline & & $\mathrm{m} 2$ & - & 0 & 1 & 30 & 16 & 30 & 2 & 17 \\
\hline & & $\mathrm{sp}$ & - & 0 & 6 & 160 & 45 & 196 & 60 & 36 \\
\hline & \multirow{5}{*}{ Male } & $t$ & - & 13 & 5 & 1 & 1 & 5 & 43 & 29 \\
\hline & & $\mathrm{im}$ & - & 13 & 48 & 18 & 0 & 2 & 5 & 9 \\
\hline & & $\mathrm{m}$ & - & 2 & 93 & 273 & 88 & 813 & 891 & 354 \\
\hline & & $\mathrm{m} 2$ & - & 0 & 0 & 3 & 0 & 0 & 0 & 0 \\
\hline & & sp & - & 0 & 0 & 35 & 11 & 55 & 21 & 44 \\
\hline \multirow{10}{*}{$\begin{array}{l}\text { Yugorskiy } \\
\text { Peninsula, } \\
\text { Amderma } \\
\text { settlement }\end{array}$} & \multirow{5}{*}{ Female } & $\mathrm{t}$ & 4 & 0 & 0 & 1 & 5 & 0 & 3 & 0 \\
\hline & & $\mathrm{im}$ & 28 & 5 & 0 & 0 & 9 & 3 & 27 & 23 \\
\hline & & $\mathrm{m}$ & 15 & 69 & 72 & 153 & 77 & 18 & 104 & 77 \\
\hline & & $\mathrm{m} 2$ & 5 & 4 & 0 & 0 & 3 & 2 & 99 & 4 \\
\hline & & $\mathrm{sp}$ & 27 & 25 & 18 & 12 & 4 & 5 & 31 & 26 \\
\hline & \multirow{5}{*}{ Male } & $t$ & 1 & 0 & 0 & 3 & 17 & 2 & 2 & 0 \\
\hline & & $\mathrm{im}$ & 13 & 8 & 0 & 0 & 5 & 3 & 12 & 15 \\
\hline & & $\mathrm{m}$ & 35 & 68 & 80 & 176 & 55 & 21 & 98 & 48 \\
\hline & & $\mathrm{m} 2$ & 0 & 0 & 0 & 0 & 0 & 0 & 0 & 0 \\
\hline & & $\mathrm{sp}$ & 6 & 4 & 4 & 2 & 6 & 3 & 7 & 3 \\
\hline \multirow{10}{*}{$\begin{array}{l}\text { Yamal } \\
\text { Peninsula, } \\
\text { Seyakha } \\
\text { settlement }\end{array}$} & \multirow{5}{*}{ Female } & $t$ & - & 0 & 0 & 0 & 0 & 0 & 0 & - \\
\hline & & $\mathrm{im}$ & - & 16 & 17 & 4 & 2 & 7 & 3 & - \\
\hline & & $\mathrm{m}$ & - & 1 & 13 & 10 & 21 & 47 & 38 & - \\
\hline & & $\mathrm{m} 2$ & - & 0 & 0 & 1 & 1 & 1 & 1 & - \\
\hline & & $\mathrm{sp}$ & - & 0 & 3 & 3 & 1 & 1 & 7 & - \\
\hline & & $\mathrm{t}$ & - & 1 & 1 & 0 & 0 & 0 & 0 & - \\
\hline & & $\mathrm{im}$ & - & 10 & 6 & 1 & 7 & 1 & 2 & - \\
\hline & Male & m & - & 3 & 21 & 20 & 13 & 53 & 28 & - \\
\hline & & $\mathrm{m} 2$ & - & 0 & 0 & 0 & 0 & 0 & 0 & - \\
\hline & & $\mathrm{sp}$ & - & 0 & 1 & 0 & 1 & 4 & 0 & - \\
\hline
\end{tabular}

Legend: $\mathrm{t}$ - teneral, im — immature, $\mathrm{m}$ - mature, $\mathrm{m} 2$ - old-mature, $\mathrm{sp}$ - spent; «-》 material was not collected

Обозначения: $\mathrm{t}$ - ювенильные особи, im - незрелые особи, $\mathrm{m}$ - половозрелые особи, $\mathrm{m} 2$ - повторно размножающиеся особи, $\mathrm{sp}$ — постгенеративные особи; «—»- материал не собирался 